\title{
Multi-level water governance without integrated water resources management (IWRM): cooperation in the Columbia River Basin
}

\author{
Armando Gallo Yahn Filho
}

${ }^{1}$ Institute of Economics and International Relations at the Federal University of Uberlândia (UFU) Uberlândia/MG. Brasil.

\begin{abstract}
International basins are divided into sub-basins that can be managed at the international, national and local levels, separately or together. Regarding the international level, many actors, beyond the States, participate in water management. This work is a case study on the Columbia River Basin (CRB), which is shared by the United States and Canada and its waters drain off into the Pacific Ocean. There are two theoretical foundations: multi-level governance and integrated water resources management (IWRM). Then, this work will demonstrate the impossibility of implementing IWRM in the CRB, even though there is multi-level governance within it, which allows cooperation between the United States and Canada, avoiding the risk of conflict in this basin.
\end{abstract}

Keywords: Multi-level governance, integrated water resources management, transboundary waters, Columbia River Basin, cooperation.

São Paulo. Vol. 23, 2020

Original Article

DOI: http://dx.doi.org/10.1590/1809-4422asoc20180263r2vu2020L4AO 


\section{Introduction}

The Columbia River is the fourth-largest river on North America, traveling 1,243 miles before reaching the Pacific Ocean. It drains an international basin that covers 258,000 square miles, which is shared by the United States of America and Canada. The Columbia River Basin (CRB) is shared by one Canadian province (British Columbia) and five American states: Idaho, Montana, Nevada, Oregon, Utah, Washington, and Wyoming, as shown in Figure 1.

\section{Figure 1 - Columbia River Basin}

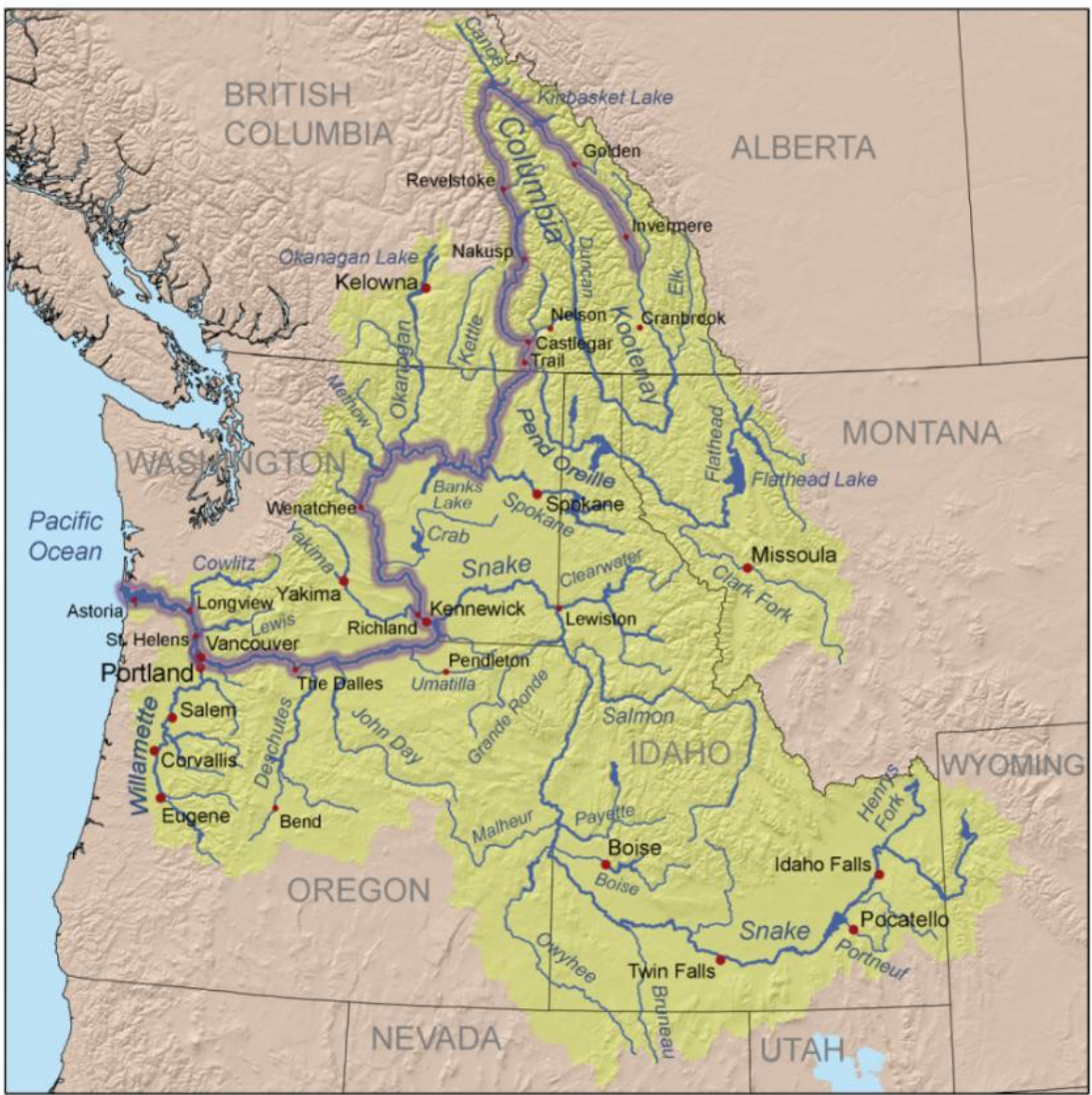

Source: American Rivers, 2016.

The research project "Basins at Risk" (BAR), coordinated by Prof. Aaron T. Wolf at the Oregon State University (OSU), created the "BAR scale", which varies from -7 (highest conflict degree) to +7 (highest cooperation degree) (WOLF et al., 2003). Wolf's research identified the international basins with potential for conflict in the last fifteen 
years. The CRB is out of risk like all others in North America, as shown in Figure 2. In other words, the CRB is in a cooperation status.

Figure 2 - International River Basins

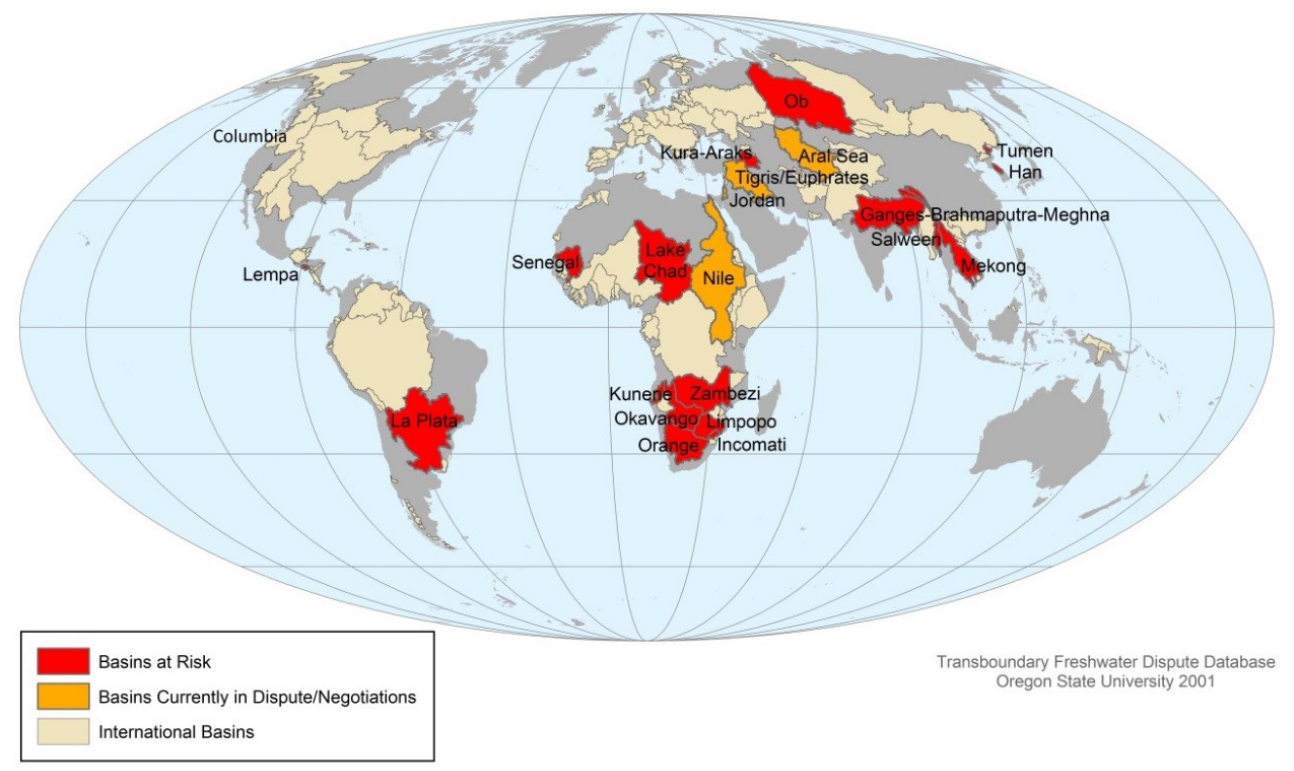

Source: Transboundary Freshwater Dispute Database (TFDD), 2001.

Taking the data from Wolf's research, I decided to put the following research problem for my study: How is the cooperation in the CRB influenced by the participation of many sub-national actors in the basin management, in both co-riparian countries?

As soon as I started my study, examining the concepts of water governance and integrated water resources management (IWRM), I verified that the existence of water governance would not lead logically to IWRM overtime. Therefore, I added a second research problem: Why is it so difficult to reach IWRM in the CRB?

Considering multi-level governance and politics of scale together, it is logical to support the necessity of involving all political scales in water basin management. Then, I will present some successful cases that have occurred recently in the CRB linked to the first research question. After this, aiming to work with the second problem, I will take as reference six indispensable factors that are necessary to reach IWRM in a basin, in order to demonstrate that the actuality of the CRB is at odds with these factors and, therefore, it is impossible to reach IWRM in this basin. 


\section{The difference between water governance and integrated water resources management (IWRM) in an international water basin}

According to GRIGG (2015, p. 1082), "within systems of governance, the term water resources management usually means the decision process for control of natural and infrastructure systems to handle water in the best interests of society". However, it is important to note that the concept of water governance is not the same of that which defines IWRM, and this difference can be more perceptible in an international basin. Although both concepts are associated to the idea of process, IWRM is the end of a process based on water governance. In other words, water governance does not necessarily lead to IWRM.

The Global Water Partnership (2000, p. 22) establishes that

IWRM is a process which promotes the coordinated development and management of water, land and related resources in order to maximize the resultants economic and social welfare in an equitable manner without compromising the sustainability of vital ecosystems.

On the other hand, the Commission on Global Governance (apud ALLOUCHE et al., 2006, p. 6) affirms that

Governance is the sum of the many ways individuals and institutions, public and private, manage their common affairs. It is a continuing process through which conflicting or diverse interests may be accommodated and co-operative action may be taken.

It is possible to verify that a key element that distinguishes the two concepts above is the coordination, which "is an important tool integration because the arena of water management sometimes involves conflicting objectives" (GRIGG, 2003, p. 222).

However, we cannot confuse coordination with cooperation. According to Grigg (2003, p. 222), "cooperation is also a key element in integration, whether by formal or informal means" and it can be understood as "any form of working together to manage water, such as in cooperative water management actions on a regional scale, often known as 'regionalization'” (GRIGG, 2003, p. 222).

Considering IWRM in an international water basin, coordination should logically be undertaken by a supranational institution, with participation of all riparian countries, whereas cooperation can be done by many kinds of institutions acting as a network through regional projects within the basin. Therefore, cooperation can occur with the participation of many actors - such as subnational governments and non-governmental actors - without a supranational organization to coordinate the process.

Another important point is that the concept of coordination changes when applied to water governance or IWRM, both in an international water basin. In the first case, it is possible a coordination made by a group of many actors involved in the water 
management, including many institutions from riparian countries acting together. In the second case, coordination should be done by a single supranational institution with decision-making autonomy.

It is important to observe that during the last decades many international institutions without decision-making autonomy have been composed by representative members from the riparian states' governments. In other words, the decision-making power of these institutions is under the national governments.

Governance does not occur without the participation of many institutions. As it happens in the construction of a world order, the impossibility to reach a single supranational autonomous organization is not an obstacle to create many other institutions (from local to international level), in order to catalyze as widely as possible a dialogue among the greatest number of actors within the water basin.

Therefore, governance is a paradigm because it has been an opportunity for new actors' participation, but it is also an obstacle to reach IWRM. As more actors are involved in the process, it is more difficult to create a supranational institution with the convergence of interests from all its members.

\section{Multi-level governance and international water management in the Columbia River Basin}

As noted in several case studies, international water management includes the participation of many actors from all sectors of civil society - pubic entities, private firms, NGOs, universities, and private citizens. Moreover, "the watershed can involve many territorial unities, like those within the own basin, and others with administrative features, like municipal, state/provincial and also international ones" (RIBEIRO, 2008, p. 31).

According to Marks (apud BACHE; FLINDERS, 2004, p. 3), multi-level governance is "a system of continuous negotiation among nested governments at several territorial tiers", which are inserted inside policy networks that surpass the public sphere's limits.

The idea of the necessity of governance derives from the great variation of externalities arising from the provision and management of public goods. And these externalities are not internalized by a single scale of government, but rather require negotiations among many scales to reach a satisfactory final decision. Many times these negotiations involve the participation of social sector organizations, such as non-governmental organizations, enterprises, etc. (MARKS; HOOGHE, 2004)

According to Allouche et al. (2012, p. 11), "multi-level governance simply refers to the fact that the emerging governance practices at the various levels - local, national, regional and global - somehow need to be connected to one another", requiring "some sort of mechanism to articulate, manage and control the interlinkages between the different governance levels, an articulation that would have to be performed by an actor, which so far does not exist" (ALLOUCHE et al., 2012, p. 11). This definition is applied to "coordinator".

In this point, it is important to note that recognizing the inexistency of such kind 
of coordinator for international water management all over the world, Allouche et al. (2012) can only be referring to an autonomous supranational institution, because other transgovernmental actors already exist in many international basins.

As I will demonstrate below, the CRB management began from formal top-down governance in 1909, and has evolved to informal bottom-up governance since 1961. This latter type of governance is consistent to what Mitchell (1990) and Conca (2010) consider as being one determinant factor to reach IWRM.

Changing the context, Vogel (2012, p. 281) argues that "we live in an era when there is a strong movement to devolve natural resource management to smaller-scale jurisdictions, and reorganize it into more natural territories such as watersheds".

However, Norman (2015, p. 79) argues that the difficulties to restructure the water management from multi-level governance "are compounded when the watershed spans international boundaries - adding a level of political complexity when federal governments are required for negotiations".

Timboe and Carter (2015) developed their work in partnership with the Universities Consortium on Columbia River Governance (UCCRG), with the objective of highlighting "several initiatives that have emerged over the years to facilitate transboundary administration and cooperation on a wide variety of water management" (TIMBOE; CARTER, 2015, p. 5), considering that

The international Columbia River basin contains a diverse set of stakeholders working at many different levels on a variety of regional issues such as improving ecosystem functioning, anadromous fish reintroduction, invasive species mitigation and prevention, sustainable energy production, and Tribal treaty rights protection. (TIMBOE; CARTER, 2015, p. 5)

As I will demonstrate, paradoxically, in the CRB, multi-level governance has not emerged as a facilitator but as a complicating factor to IWRM, exactly because of the participation of many actors. However, the participation of new actors in the basin management has shown more localized efficiency, in restricted spaces within it. Therefore, multi-level governance resulting in cooperative international basin management, even without IWRM, seems to be possible only if the national governments are not so prominent as to dominate the process and also if an articulation between the subnational actors across the boundaries is done.

\section{Politics of scale and water governance: the Columbia River Basin case}

According to Norman et al. (2015, p. 2), "negotiating water governance requires explicit consideration of the politics of scale" due to "three interrelated points: 1) that hydrologic scales such as river basins and watersheds should not be taken for granted as natural and apolitical scales; 2) that the historical legacies of water governance inform current decision-making, including efforts to rescale water governance; and 3) that scales 
are political tools" (NORMAN et al., 2015, p. 2).

They also argue that "water governance debates address the mechanisms and institutional frameworks through which decisions about water are made" (NORMAN et al., 2015, p. 3). Then, "the rise of watersheds is often seen as an example of rescaled environmental governance - a term used to refer to a shift in the locus of decisionmaking" and "the relationship between scale and water governance is a departure from the scalar debate's usual focus on political economy and flows of capital" (NORMAN et al., 2015, p. 3).

Brenner (2004) considers that there is a decrease of the state centralization in the national regulatory process, but that sharing of responsibilities with other political scales does not remove the state's role in the national development process. In accordance with Brenner's thoughts, Norman and Bakker (2009, p. 64) argue that

(...) despite the increase in the number of local - and decline in new federal - instruments to govern transboundary water, the nation state remains a key instrument in negotiating transnational water issues. In other words, rescaling is not leading a hollowing out of the state, nor to a new localism.

In the case of the CRB, the British Columbia-Washington Environmental Cooperation Council (ECC), created in 1992, is an example of "transboundary water governance at the provincial-state scale, that is, the relevant states and provinces dealing directly with one another rather than through the federal governments" (NORMAN 2015, p. 55). However, the ECC also includes two members which "represent regional offices of federal agencies, the U.S. Environmental Protection Agency (region 10) and Fisheries and Oceans Canada (Pacific region)" (NORMAN, 2015, p. 58), so that the ECC's structure "aims to provide a balanced perspective between the countries at both federal and subnational scale" (NORMAN 2015, p. 58).

Therefore, regarding international water basins, even recognizing the role of multilevel governance, it is not possible to fully apply the concepts underlying IWRM because the coordination will be submitted to institutions under the national government's decision-making power rather than to an independent supranational organization with complete autonomy.

\section{Integrated Water Resources Management (IWRM) and its limits when applied to the Columbia River Basin}

According to Mitchell (1990), Grigg (2008), and Savenije and Van Der Zaag (2008), there are three key-elements to be considered for interpreting the concept of IWRM (as described in item 2): 1) the fact that water is a system that must be treated in many dimensions (surface water and groundwater, quantity and quality);2) the fact that any water system interconnects with other social and economic sectors, as well as natural systems (soil, air and the broader environment); and 3) the importance of making a water 
management taking into account other policies related to economic development and environmental management, in order to reach a sustainable development.

Conca (2010, p. 126) argues that "IWRM is interpreted in two related but distinct ways: 1 ) as an increasingly clearly specified conceptual blueprint; and 2) as an increasingly embedded, institutionalized set of transnational relationships".

Taking the considerations above, once more it is clear that it is impossible to apply the full suite of what IWRM includes in an international water basin unless all sub-basins work simultaneously and interact through transnational governance. Therefore, there will not be IWRM in the context of multi-level governance if an attempt to create a supranational institution precedes the bottom-up governance.

\subsection{Indispensable factors to reach IWRM}

Taking as reference critical studies on IWRM from some experts, such as Mitchell (1990), Biswas (1998), Grigg (2008), and Savenije and Van Der Zaag (2008), it is possible to highlight six indispensable factors to reach IWRM: 1) context; 2) legitimation; 3) functions; 4) structures; 5) processes and mechanisms; 6) organizational culture and attitudes.

Then, it will be demonstrated bellow that the actuality of the Columbia River Basin (CRB) is at odds with these factors, and therefore it is impossible to reach IWRM in this basin, even though there is multilevel governance within it.

\subsubsection{Context}

According to Savenije and Van Der Zaag (2008, p. 291), "both the water resources themselves and the water uses have distinct temporal patterns", so that IWRM must consider the "temporal scale, taking into account the temporal variation in availability of and demand for water resources, but also the physical structures that have been built to even out fluctuations and to better match the supply with demand" (SAVENIJE; VAN DER ZAAG, 2008, p. 291).

In this sense, Mitchell (1990, p. 8) argues that:

In assessing the nature of, or opportunities of, integrating water and land resources it is essential to recognize the broader contextual aspects which alone or in combination may trigger a desire to pursue integration. (...) The nature of the bargaining varies, however, depending on the diverse decision rules, traditions, legal authority and professional orientation appropriate to the situation.

Then, Mitchell (1990) points out four sub-factors deserve attention regarding context: 1) the state of natural environment; 2) Prevailing ideologies; 3) Economic conditions; 4) Legal, administrative and financial arrangements.

Taking the state of natural environment, when the Boundary Waters Treaty (BWT) 
was signed, in 1909, there was very little preoccupation with hydropower, unlike when the Columbia River Treaty (CRT) was signed in 1961. In the early years of the last century relatively few dams had been constructed and public concern over this infrastructure was nearly nonexistent. The countries' major concern was political preoccupation with their boundaries and respective national territories. By 1961 both the pace of approving new dams and their numbers in the CRB was causing problems on both sides of the border. The CRT was signed based on two main problems: flood control and hydropower generation. In recent years, the debate on the state of the natural environment involves many other issues that were not considered in the 1960's, such as climate change and salmon, demanding the CRT's revision.

Regarding ideologies, the contextual differences since 1909 are also remarkable. While the BWT was negotiated between political representatives from both countries, without influence of subnational actors, the CRT included new actors, bringing many ideologies to the debate. Complicating this situation, nowadays these ideologies involve new "sovereigns" - such as the First Nations and Native Americans tribes -, NGOs, academics, among others. Hence, in the first context, ideologies were limited to the political parties in control of the decision process, whereas in the second and third contexts, many other actors with diversified ideologies have been involved in the debate.

Turning to the economic conditions, they were very tied to the state of natural environment regarding hydropower, when the CRT was signed. From a system perspective, that has changed dramatically, not only related to the increasing demand for energy but also the emergence of many other multiple uses of water. Therefore, with increased interest and input to the decision process, it has become more difficult to reaching convergence among all actors. Moreover, taking the principle of sustainability, although the CRB developments - with dams generating hydropower and controlling water flows have supported the region's economic prosperity, they "have substantial adverse effects on the basin's fish and wildlife, the river conditions that support this biological diversity, and the people who value those fish, wildlife, and river amenities" (SHURTS; PAISLEY, 2013, p. 143).

Finally, regarding legal, administrative and financial arrangements, important contextual differences are also apparent. From 1909 to 1961, the decision-making process was centralized in the International Joint Commission (IJC), which "comprises six members, three appointed by the Governor in Council in Canada and three by the President of the United States and confirmed by the U.S. Senate" (NORMAN, 2015, p. 49), characterizing a federal-federal model of governance. With the CRT, although IJC has not been eliminated, it has not fully accommodated the socioeconomic changes that have occurred within the basin, more specifically related to the participation of new actors in the water management. Regarding legality, the regularization process in the CRB is more complicated due to the lack of a national water management law in the United States, so that states hold distinct opinions for access and use of water in the same basin. Although Canadian laws on water resources are also provincial, the difference from the United States is that the CRB is within a single Province - British Columbia. 
Therefore, all these contextual changes have been a complicating element to reach agreement on IWRM. Then, I defend Vogel's idea of multi-level governance with parallel agreements and institutions, working simultaneously (VOGEL, 2012).

\subsubsection{Legitimation}

According to Mitchell (1990, p. 8):

As boundary effects will inevitably be present, it is essential to identify: (1) the objectives of pertinent agencies, (2) the responsibility, power or authority of these agencies and (3) the rules for intervention and arbitration by higher level authorities when conflicts arise which cannot be resolved by the participants directly involved.

In 1961, when the CRT was signed, the agencies' objectives seemed to be clear in comparison to the political interests behind the law after the inclusion of new actors in the process overtime. However, analyzing the CRB management from 1960's onward, it is necessary to take into account the interest changes. The CRT has been the base for an expected integrated management, including many interested actors on the basin's waters. Nevertheless, as much as the number of actors has grown in this multi-level governance, the interests have not been absorbed by the CRT. According to Wolf et al. (2003, p. 43), "the likelihood and intensity of a dispute rises as the rate of change within a basin exceeds the institutional capacity to absorb that change".

The main problem is the difficulty to put all interests under a single "umbrella law" applied to all government levels and the impossibility of putting all actors in a same supranational institution which coordinates the water management process without the influence of national governments. Taking the factor "inclusivity" when working the participation of sovereign entities during the US Review of the CRT, Ogren $(2015$, p. 245) argues that "even though stakeholders and some sovereigns felt there should be greater representation, both acknowledged the challenge of including so many people in the room".

According to Mitchell (1990, p. 9):

Even when objectives and powers are stated explicitly, there is still a strong probability of conflicts between participating agencies as a result of boundary effects. Thus, it is important to identify who has the right and duty to intervene to resolve such impasses.

According to the Article XVI of the CRT, "differences arising under the Treaty which Canada and the United States of America cannot resolve may be referred by either to the International Joint Commission for decision" (UNITED STATES OF AMERICA; CANADA, 1961, p. 11). However, the International Joint Commission (IJC) has a rather weak record in resolving conflicts, particularly those related to highly technical issues. As McCaffrey et al. (2012, p. 377) points out, "academic institutions may also have a 
key role to play as third parties through neutral fact finding, facilitation, and capacity building". In this case, one good example is the Universities Consortium on Columbia Basin Governance, which "came about to bring research informed by stakeholder input to bear on the issues of importance to both the U.S. and Canada in the Pacific Northwest (PNW) prior to the change in status of the Columbia River Treaty in 2024" (MCCAFFREY et al., 2012,p. 377).

Regarding the third point presented by Mitchell related to the legitimation of IWRM, McCaffrey et al. (2012) highlight that one failing of the CRT, and the BWT as well, is the lack of precise details on conflict management between the two countries. Therefore, although the IJC was created as an institution for conflict management in 1909 , it has never had legal base to actually resolve problems.

\subsubsection{Functions}

According to Savenije and Van Der Zaag (2008, p. 91), "water resources issues are apparent at different levels and hydrological boundaries seldom concur with administrative boundaries". Although the river basins are the most appropriate units for operational management, there are institutional problems due to different entities which have different spatial logic (GRIGG, 2008; SAVENIJE; VAN DER ZAAG, 2008).

Regarding these problems, Mitchell (1990, p. 10) argues that "a key concern should be to determine which management functions should be assigned to which scale or hierarchy (local, state, and federal)".

In the case of transboundary basins, the international scale is at stake. Then, international regimes and organizations determine the legitimation of IWRM, although they can continue to work in parallel to institutions that are in other government levels. However, to reach IWRM it is necessary to involve all actors of the process; that is, an apparent impossibility in a complex international basin.

This international scale reminds us about the problem of coordination in an international water basin management. In the case of IWRM, this coordination should be done by a supranational institution with autonomous decision-making power, and also composed by a technical staff. Nevertheless, it is something that does not exist yet in an international basin, as highlighted by Allouche et al. (2006).

In the case of the CRB, "the [national] Entities have each appointed treaty coordinators and a secretary, and established a joint treaty-operating committee from agency personnel to oversee annual planning and operations under the treaty" (SHURTS; PAISLEY, 2013, p. 146). However, it is not an autonomous supranational institution. Regarding the transboundary issues addressed at multiple scales in the CRB, Timboe (2016) affirms that transboundary cooperation is happening at all spatial and hierarchical scales, but some scales (such as the international one) are weaker than others.

Therefore, international water management does not imply necessarily a single institution of coordination, but at least an interdependent management through which countries work together in a cooperation process. This goal can be achieved through 
many institutional models (public or private; national or international) acting as a network toward a shared goal.

According to Biswas (2008, p. 20), "water management must be responsive to the needs and demands of a growing diversity of central, state and municipal institutions, user groups, the private sector, NGOs and other appropriate bodies". Regarding this tendency, it is important to stress Mitchell's argument that the functions related to water management "should be allocated whenever possible to the scale or hierarchy that has the closest relationship to those people receiving the service or product" (MITCHELL, 1990, p. 10).

It strengthens my argument, in accordance to Vogel (2012), that the diversity of functions in the agenda of the CRT's revision should be attributed to local institutions managed from specific laws applied in parallel to the Treaty.

According to Mitchell (1990, p. 11):

Different mixes of scales, generic and substantive functions will be appropriate in different situation. (...) It may well be that the alignment made excellent sense at the time decisions were taken, but in many instances those decisions were made previously when the context and conditions were significantly different.

Once more, it can be verified the importance of history and context to interpret the CRT and to know how to apply it in face to the economic, social, political, and environmental changes that have occurred since it was signed.

\subsubsection{Structures}

If a particular structure or investment is created to attend to a specific function related to water basin management, it can also cause a secondary problem given the need to manage the basin as a whole, joining the elements water, land, air and ecosystem (MITCHELL, 1990).

In this sense, Biswas (2008, p. 17) affirms that "water, energy, agriculture, the environment or rural development are becoming increasingly interrelated and interdependent", so that "integrated management of any one of these resources is not technically possible and institutionally and managerial feasible, because of accelerating overlaps and interlinkages with the other resource and development sectors" (BISWAS, 2008, p. 17).

As I have already demonstrated, the British Columbia-Washington Environmental Cooperation Council is a good example of how the institution's structure hindered its own functions, preventing it to reach IWRM.

In the actual context, it is possible to observe many institutions overlapping functions in the CRB. Timboe (2016, p. 65) reports:

Work is being done to integrate the various basin monitoring programs, but comprehensive data harmonization between the United 
States and Canada remains elusive. (...) While basin-wide coordination cannot solve all of the problems that plague the river ecosystem, working solely at the sub-watershed level has also proved insufficient. Because the sub-watersheds are inextricably linked systems, nested networks of governance are needed, including, and perhaps especially, at the basin-scale.

Another important fact reported by Timboe (2016, p. 42) is that

State and federal employees are also involved with improving ecosystem function throughout the basin. Often times, state and federal agencies partner with tribal and non-profit groups in order to complete habitat recovery or water quality monitoring projects. At this time, however, some federal employees working in the basin are being prevented from interacting with their international counterparts.

Thus, it is more practicable to leave multi-level governance occurs, with the creation of local institutions with specific functions and regulations, rather than through a treaty which cannot absorbs all issues related to the basin management. That is, more individualized agreements among willing stakeholders rather than formalized top-down policy offer greater flexibility to managers (VOGEL, 2012).

Although the rescaling process is done with the state redistributing its functions to local institutions, and dividing its responsibilities with subnational governments, it is important to understand that some functions are still under the responsibility of the federal government.

\subsubsection{Processes and Mechanisms}

According to Mitchell (1990, p. 13):

No matter how carefully considered and designed, the legitimation, functions and structures are unlikely to fit together perfectly. The presence of loose ends because of imperfect fits suggests the need for processes and mechanisms to facilitate bargaining, negotiation and mediating at the boundaries.

At the political level there are two processes: interministerial councils and select committees. The former "are often used to ensure that pertinent Cabinet Ministers meet to share views" (MITCHELL, 1990, p. 13), while the latter "may also be used when it is thought that a specific problem requires investigation by a group representing a crosssection of the political ideologies prevailing in a state or country" (MITCHELL, 1990, p. 13).

At the bureaucratic level, a mechanism that has been used to facilitate integration 
and coordination for water management is the interdepartmental committee, which is "occasionally given the status of commission" and "used to provide a forum for exchanging information and ideas about ongoing and proposed activities" (MITCHELL, 1990, p. 13). However, there is a problem with this structure, as noted by Mitchell (1990, p. 13):

A common weakness of such committees is that they are given little power and therefore are placed in a weak position to effect change. Paterson (1986, p. 101) has aptly characterized them as the 'interdepartmental committee of fudges and compromises' which are ineffective not because of the inability of the participants but as result of the fundamental constraints associated with their real authority.

Studying international basins, it is important to highlight that basin committees may be composed by subnational governments and non-governmental actors, but the national governments do not give them decision-making authority, many times considering that it is an issue of national and economic security. Therefore, many economic sectors, composing lobbies, press the national government's decision-makings and hinder the committee's efficiency, more specifically when the issues at stark threat their own interests.

Regarding the CRB, the British Columbia-Washington Environmental Cooperation Council is an example of how multi-level governance does not necessarily apply to IWRM, because of the lack of authority and decision-making power given to the subnational actors by the national governments in the rescaling process. Then, it is impossible to create a supranational mechanism for water management under subnational actors' coordination and completely autonomous from national governments because if the state does not give one-hundred percent of decision-making authority to its subnational governments, then it will not transfer all its sovereignty to a supranational institution.

According to Savenije and Van Der Zaag (2008, p. 291), "interests and decisions at lower levels need to be carried upward to be taken into consideration at higher levels, particularly to the national and international levels". However, Biswas (2008, p. 20) argues that "stakeholders' participation and a bottom-up approach at the micro-level are often unlikely to contribute to 'integration' at higher levels".

It is important to consider that the overture for public participation is done through committees for national basin management, which are sometimes sub-basins of international basins. Therefore, taking the basin as a system, it would be necessary to involve all committees from all national sub-basins within the international one in order to reach an IWRM. An alternative to this model would be the creation of a supranational committee composed of representatives from all management units within the international basin. It seems to be difficult not because of the mechanism per se, but it seems unlikely that all sub-basins have adopted the committee structure.

Regarding the CRB, the idea of international watershed boards created by the IJC's International Water Initiative was associated to the difficulty of managing a wide international area, involving all actors that live within it (CLAMEN, 2013). However, if 
it has been difficult to apply the concept of integration to international sub-basins (international watershed boards), then it is obvious the impossibility of doing this in whole international basin.

Besides the chosen mechanisms, a variety of processes can be drawn upon to pull together diverse viewpoints, such as: regional planning, benefit cost analysis, environmental impact assessment and public participation (MITCHELL, 1990). All these processes are presented in the debate on the CRT's revision.

\subsubsection{Organizational Culture and Attitudes}

According to Mitchell (1990, p. 14):

Ultimately, integration, co-operation and co-ordination depend to a significant extent upon the willingness of the participants to make them happen. (...) People who are inclined to co-operate and are enthusiastic can often make a poor system work well. Conversely, a well-designed system may falter if the participants are determined not to work with each other.

Noting this point, it is necessary to highlight that international law "cannot be understood independently of the political foundation on which it rests and of the political interests which it serves" (CARR apud KOSKENNIEMI, 2012, p. 11). Therefore, treaties must be interpreted carefully, because the real interests of many actors are not always expressed through words. Even if they are clearly expressed, their interpretations may change overtime, weather by the signatories themselves or because the new actors or situations which are involved in the process.

It is important to note that, in all countries, there are many interests behind international treaties. Disagreement is a normal part of the process of planning and adopting any treaty, which can be signed but not ratified. Another important point is related to the fact that international institutions, such as International Joint Commission, are composed of representatives from each co-riparian country. Therefore, behind each representative there are many interests that cause difficulties for negotiations, growing divergences rather than facilitating convergences among the involved parties.

Therefore, Mitchell (1990) argues that organizational culture is linked to the idea that many public agencies are naturally preoccupied with their own interests rather than with the broader societal welfare. In the international level, more specifically in an international water basin, it is important to take into account the interests of all those actors from each riparian country.

Returning to the problems of new actors and interests, as well as the lack of empowerment given to the water management institutions, Mitchell (1990, p. 15) points out:

Whereas society may gain through more co-ordination and co-operation among public agencies, some individuals will perceive themselves 
as becoming losers through reduction in or loss of authority, shrunken empires and reduced leverage of influence. In such situations, lip service may be given in support of integration, but in practice low-risk strategies such as delay, systematic disinformation and minor sabotage will be utilized to hinder its implementation.

Otherwise, Mitchell (1990) recognizes that informal bottom-up governance and rescaling of the state could be alternatives for the organizational culture.

\begin{abstract}
As with processes and mechanisms, being aware of the informal activities which can promote or hinder integration is important. In a positive sense, action can be taken to arrange informal meetings to discuss matters of mutual interest and concern, to cultivate a network of key contacts and sources of information, to place people on key committees and to befriend officials at various scales or hierarchy of government. (MITCHELL, 1990, p. 16)
\end{abstract}

I have already demonstrated the obstacles created by the rescaling of the state for an international basin management. However, informal bottom-up and multi-level governances are good alternatives to which CRB has adapted recently. Therefore, once more, it is clear that the Columbia River Treaty is not the best alternative for the management of this international basin.

\title{
6 Conclusions
}

In this work, I have demonstrated that integrated water resources management (IWRM) is the end of a process based on water governance, but the latter does not necessarily lead to the former. Although both processes are based on cooperation, IWRM also depends on coordination, articulating many actors in different scales. At the international level, this coordination implies a supranational institution with autonomous decision-making power, which does not exist in the Columbia River Basin and in any other international basin of the world as well. However, in the Columbia River Basin, Canada and the United States have demonstrated ability to cooperate based on multilevel water governance, even though it is unlikely to reach IWRM.

It is important to highlight the difference between two types of transnational water governance: formal top-down and informal bottom-up. Although the latter is a base for applying IWRM, in the Columbia River Basin the historical management process was based on the former, with some changes that have occurred in recent years. Unlike the Boundary Waters Treaty (1909), the Columbia River Treaty (1961) included subnational actors in its negotiations, and recently many other actors are being involved in the Basin management, such as First Nations and Native American tribes.

Paradoxically, multi-level governance has been an obstacle rather than a facilita- 
tor for IWRM in the Columbia River Basin, because as more actors are involved in the process, it is more difficult to create a supranational institution with the convergence of interests from all its members. However, at the same time, the participation of new actors in the basin management has shown more localized efficiency. Therefore, it seems to be possible to apply aspects of multi-level governance resulting in cooperative international basins even without reaching IWRM.

Although rescaling of the state can open the doors for new actor's participation, it hinders multi-level governance to fully apply IWRM because it keeps the formal top-down transnational governance. Therefore, there will not be legitimation of IWRM if the riparian states keep working supranational institutions, like International Joint Commission, which precede the informal bottom-up governance. This kind of institutional structure composed of representatives from national governments highlights the functional problem of non-empowerment of subnational actors.

Finally, I point out the problem of organizational culture to reach IWRM in an international basin. In the case of the Columbia River Basin, Columbia River Treaty and International Joint Commission have been the main juridical and institutional elements and they cannot absorb all interests at stake. Therefore, I defend that Columbia River Basin management should be undertaken from informal bottom-up and multi-level governances approaches instead of through a formal treaty, which may be always out of context due to the fast social, political, economic and environmental changes.

\section{Acknowledgment}

I thank CAPES (Coordenação de Aperfeiçoamento de Pessoal de Nível Superior), in Brazil, for providing my scholarship from September 2015 to August 2016 (Process number 99999.000518/2015-08), allowing me to develop my post-doctoral research at Oregon State University, in the USA, under the direction of Professor Aaron T. Wolf.

\section{References}

ALLOUCHE, J.; FINGER, M.; TAMIOTTI, L. Introduction: conceptual elements. In: ALLOUCHE, J. et al. (Ed.). The multi-governance of water: four case studies. New York: Suny Press, 2006, p. 1-42.

AMERICAN RIVERS (Cartog.). Columbia River Basin. Washington, DC, 2016. Available in: www.americanrivers.org/river/columbia-river/. Access in: 15 jun. 2016.

BACHE, I.; FLINDERS, M. Themes and issues in multi-level governance. In: . Multi-level governance. Oxford: Oxford University Press, 2004, p. 1-11.

BISWAS, A. Integrated Water Resources Management: Is It Working? International Journal of Water Resources Development, vol. 24, n. 1, p. 5-22, 2008.

BRENNER, N. New State Spaces: urban governance and the rescaling of statehood. Oxford: 
Oxford University Press, 2004.

CLAMEN, M. The IJC and transboundary water disputes: past, present and future. In: NORMAN, E. S. (Ed.). Water without borders? Canada, the United States and shared waters. Toronto: University of Toronto Press, 2013, p. 70-87.

CONCA, K. Governing Water. Cambridge: MIT Press, 2006.

GLOBAL WATER PARTNERSHIP. Integrated Water Resources Management. Stockholm: Technical Advisory Committee, 2000. Available in: https:/www.gwp.org/globalassets/global/toolbox/publications/background-papers/04-integrated-water-resources-management-2000-english. pdf. Access in: 20 abr. 2016.

GRIGG, N. S. Integrated Water Resources Management. In: DASCH, J. E. (Ed.). Water: Science and issues. New York: Macmillan Reference, 2003.v. 2, p. 220-223.

GRIGG, N. S. Integrated water resources management: balancing views and improving practice. Water International, vol. 33, n. 3, p. 279-292, 2008.

GRIGG, N. S. Misalignment of watershed and jurisdictional boundaries: the importance of scale. Water Policy, v. 17, n. 6, p. 1079-1092, 2015.

KOSKENNIEMI, M. Law, teleology and international relations: an essay in counterdisciplinarity. International Relations, v. 26, n. 1, p. 3-34, 2012.

MARKS, G.; HOOGHE, L. Contrasting visions of multi-level governance. In: BACHE, I.; FLINDERS, M. (Ed.). Multi-level governance. Oxford: Oxford University Press, 2004, p. 15-30.

MCCAFFREY, S. et al. The Columbia River Treaty in 2014 and Beyond: International Experiences and Lessons Learned. In: COSENS, B. (Ed.). Columbia River Treaty Revisited: Transboundary River Governance in the Face of Uncertainty. Corvallis: Oregon State University Press, 2012, p. 365-382.

MITCHELL, B. Integrated water management. In: . Integrated water management: international experiences and perspectives. London: Belhaven Press, 1990, p. 1-21.

NORMAN, E.; BAKKER, K. Rise of the local? Delegation and devolution in transboundary water governance. In: NORMAN, E. S. (Ed.). Water without borders? Canada, the United States and shared waters. Toronto: University of Toronto Press, 2013, p. 47-69.

NORMAN, E.; COOK, C.; COHEN, A. Introduction: why the politics of scale matter in the governance of water. In: NORMAN, E. et al. (Eds.). Negotiating Water Governance: Why the Politics of Scale Matter. Farmham: Ashgate Publishing, 2015, p. 1-16.

NORMAN, E. Governing transboundary waters: Canada, the United States and indigenous communities. New York: Routledge, 2015.

OGREN, K. Water Governance Process Assessment: Evaluating the Link between Decision Making Processes and Outcomes in the Columbia River Basin. 2015. Ph.D. dissertation - College of Earth, Ocean and Atmospheric Studies (CEOAS), Oregon State University, Corvallis, 2015.

RIBEIRO, W. C. Geografia política da água. São Paulo: Annablume, 2008.

SAVENIJE, H. H. G.; VAN DER ZAAG, P. Integrated water resources management: Concepts and issues. Physics and Chemistry of the Earth, vol. 33, p. 290-297, 2008. 
SHURTS, J.; PAISLEY, R. The Columbia River Treaty. In: NORMAN, E. S. (Ed.). Water without borders? Canada, the United States and shared waters. Toronto: University of Toronto Press, 2013, p. 139-158.

TIMBOE, I. Assessing the Current State of Transboundary Cooperation in the International Columbia River Basin. 2016. M.Sc. Thesis - College of Earth, Ocean and Atmospheric Studies (CEOAS), Oregon State University, Corvallis, 2016.

TIMBOE, I. AND CARTER, M. Transboundary cooperation in the international Columbia River basin: a preliminary assessment of existing arrangements and future prospects. 2015. Research prepared for The Columbia Basin Trust Northwest Power \& Conservation Council in partnership with the Universities Consortium on Columbia River Governance - College of Earth, Ocean and Atmospheric Studies (CEOAS), Oregon State University, Corvallis, 2015.

TRANSBOUNDARY FRESHWATER DISPUTE DATABASE - TFDD (Cartog.). Basins at Risk. College of Earth, Ocean, and Atmospheric Sciences, Oregon State University, 2001. Available in: http://transboundarywaters.science.oregonstate.edu. Access in: 15 jun. 2016.

UNITED STATES OF AMERICA; CANADA. Columbia River Treaty. Washington, DC, 1961. Available in: www.nwd-wc.usace.army.mil/PB/PEB_08/docs/ColumbiaRiverTreaty.pdf. Access in: 15 jan. 2015.

VOGEL, E. Can an International Treaty Strengthen a Region and Further Social and Environmental Inclusion? Lessons from the Columbia River Treaty. In: COSENS, B. (Ed.). Columbia River Treaty Revisited: transboundary river governance in the Face of Uncertainty. Corvallis: Oregon State University Press, 2012, p. 281-314.

WOLF, A. T.; PRISCOLI, J. D. Managing and transforming water conflicts. Cambridge: Cambridge University Press, 2009.

WOLF, A. T.; YOFFE, S. B.; GIORDANO, M. International waters: identifying basins at risk. Water Policy, v. 5, n. 1, p. 29-60, 2003. 


\section{Armando Gallo Yahn Filho}

๑agyahn@gmail.com

ORCiD: https://orcid.org/0000-0002-4883-6427.
Submitted on: 01/10/2018

Accepted on: 10/02/2020

2020;23:e02632

How to cite: YAHN FILHO, Armando Gallo. Multi-level water governance without integrated water resources management (IWRM): cooperation in the Columbia River Basin. Ambiente $\&$ Sociedade. São Paulo, v. 23, p. 1-20, 2020. 


\title{
Governança hídrica multinivel sem gestão integrada de recursos hídricos (GIRH): cooperação na Bacia do Rio Colúmbia
}

\author{
Armando Gallo Yahn Filho
}

São Paulo. Vol. 23, 2020

Artigo Original
Resumo: Bacias internacionais são divididas em sub-bacias que podem ser gerenciadas nos níveis internacional, nacional e local, separadamente ou juntas. No nível internacional, muitos atores, além dos Estados, participam nesta gestão. Este trabalho é um estudo de caso sobre a Bacia do Rio Colúmbia (BRC), compartilhada por Estados Unidos e Canadá, cujas águas drenam para o Oceano Pacífico. Há duas fundamentações teóricas: governança multinível e gestão integrada de recursos hídricos (GIRH). Então, neste trabalho será demonstrada a impossibilidade de implementar a GIRH na BRC, ainda que haja uma governança multinível que permite a cooperação entre os Estados Unidos e o Canadá, evitando o risco de conflito nesta bacia.

Palavras-chave: Governança multinível, gestão integrada de recursos hídricos, águas transfronteiriças, Bacia do Rio Colúmbia, cooperação.

Como citar: YAHN FILHO, Armando Gallo. Governança hídrica multinível sem gestão integrada de recursos hídricos (GIRH): cooperação na Bacia do Rio Colúmbia. Ambiente \& Sociedade. São Paulo, v. 23, p. $1-20,2020$. 


\title{
Gobernanza del agua multinivel sin gestión integrada de los recursos hídricos (GIRH): cooperación en la Cuenca del Río Columbia
}

\author{
Armando Gallo Yahn Filho
}

São Paulo. Vol. 23, 2020

Artículo original
Resumen: Cuencas internacionales se dividen en subcuencas que se pueden gestionar a nivel internacional, nacional y local, por separado o juntas. A nivel internacional, varios actores, además del Estado, participan en esta gestión. Este trabajo es un estudio de caso sobre la Cuenca del Río Columbia (CRC), compartida por los Estados Unidos y Canadá, cuyas aguas drenan hacia el Océano Pacífico. Hay dos fundamentos teóricos: gobernanza multinivel y gestión integrada de los recursos hídricos (GIRH). Por lo tanto, este trabajo demostrará la imposibilidad de implementar la GIRH en la CRC, a pesar de que existe una gobernanza multinivel que permite la cooperación entre los Estados Unidos y Canadá, evitando el riesgo de conflicto en esta cuenca.

Palabras-clave: Gobernanza multinivel, gestión integrada de recursos hídricos, aguas transfronterizas, Cuenca del Río Columbia, cooperación.

Como citar: YAHN FILHO, Armando Gallo. Gobernanza del agua multinivel sin gestión integrada de los recursos hídricos (GIRH): cooperación en la Cuenca del Río Columbia. Ambiente $\&$ Sociedade. São Paulo, v. 23, p. 1-20, 2020. 